\title{
GEOSITES AS A POTENTIAL FOR THE DEVELOPMENT OF TOURISM - OVERVIEW OF RELEVANT SITES IN ESWATINI (FORMERLY SWAZILAND)
}

\author{
Thomas SCHLÜTER ${ }^{*}$ \\ Department of Geography, Environmental Science and Planning, \\ University of Swaziland, P.B. 4, Kwaluseni, Eswatini, e-mail: thomas.schlueter2008@gmail.com
}

Andreas SCHUMANN

Department of Geology and Petroleum Studies, Makerere University, Kampala, Uganda, e-mail: geo-andy@gmx.de

\begin{abstract}
Citation: Schlüter, T., \& Schumann, A. (2018). GEOSITES AS A POTENTIAL FOR THE DEVELOPMENT OF TOURISM - OVERVIEW OF RELEVANT SITES IN ESWATINI (FORMERLY SWAZILAND). GeoJournal of Tourism and Geosites. 22(2), 535-547. https://doi.org/10.30892/gtg.22222-309
\end{abstract}

\begin{abstract}
Despite being one of the smallest countries in Africa, the Kingdom of Eswatini (formerly Swaziland) is characterized by many locations, which are due to their geoscientific significance to be termed as geosites, and which are here in an overview presented and briefly explained. Each of them can be assigned to a specific scientific approach, e.g. as a landscape, a geological, a geomorphologic, an archaeological (prehistoric) or a mining heritage site. Eswatini yields remarkable landscapes like the Mahamba Gorge and the Sibebe Monolith, it exhibits worldwide one of the largest in granite formed caves (Gobholo), and possibly the oldest dated rocks in Africa (Piggs Peak gneisses), as well as beautiful and scientifically relevant rock painting sites (Nsangwini, Sandlane and Hholoshini) and three abandoned mines in the Barberton Greenstone Belt (Forbes, Ngwenya and Bulembu). The latter have contributed largely to the infrastructural development of the country. The geotouristic value of the respective sites is evaluated and commented, and it is assumed that in future these and other, here not yet mentioned geosites, may contribute to income generating processes for the country and the local communities.
\end{abstract}

Keywords: Eswatini (Swaziland), geoheritage, geosites, geology, geomorphology, archaeology, mining, geo-tourism.

\section{INTRODUCTION}

Landlocked Eswatini (renamed from Swaziland in April 2018) is located in Southeast Africa between South Africa bordering to the North, West and Southeast, and Mozambique to the Northeast (W: $30^{\circ} 47^{`}, \mathrm{~N}: 25^{\circ} 34^{`}, \mathrm{E}: 32^{\circ} \mathrm{O} 8^{`}, \mathrm{~S}: 27^{\circ} 18^{`}$ ). It covers an

\footnotetext{
* Corresponding author
} 
area of $17,364 \mathrm{~km}^{2}$ and has a population of about 1.3 Millions, with an annual growing rate of about $1.2 \%$. Its GDP per capita is with 9.715 US \$ in the lower middle range. Average life expectancy is with about 50 years (2015) due to the HIV/AIDS epidemic one of the lowest worldwide (Schlüter, 2013; Schlüter \& Tevera, 2016). The country can be separated into four geographical regions, which are from west to east determined by altitude: Highveld (average altitude $1200 \mathrm{~m}$ ), Middleveld (700 m), Lowveld (250 m) and Lubombo Ridge (600 m). Geographic data are summarized by Schlüter (2008). The primary premise of conservation is the protection of heritage. Geoscientific conservation involves recognising, protecting and managing sites, which may be identified as important for their rocks, minerals, fossils, landscapes, various archaeological (prehistoric) features or as former mining sites. Geoconservation or Earth heritage conservation is the broad term that refers to all aspects of conservation, the protection and management of geological, geomorphological, archaeological / prehistoric and mining related landscapes and soil sites. It is the endeavour of trying to conserve geodiversity and geoheritage (Schutte, 2009). Geosites represent places or locations where the dynamics of the Earth and the resulting geological, geomorphological and human-made features are exceptionally well indicated and preserved, sometimes yielding aesthetic landscapes or geo-historically relevant places. Often such sites have the potential of economic income in the form of "Geotourism", and they may therefore also serve for the purpose of education about environmental protection and nature conservation (Viljoen \& Reimold, 1999).

\section{GEOHERITAGE IN ESWATINI}

"Geoheritage" is generally a descriptive term applied to sites or areas of geoscientific features with significant scientific, educational, cultural and/or aesthetic value (www.geo.mtn.edu). The following four sub-categories of geoheritage are here considered being relevant and available in Eswatini: sites with 1) geological, 2) geomorphologic, 3) archaeological (prehistoric) and 4) mining heritage background.

\section{Geology}

The country`s surface geology is dominated in its western part by rocks of Precambrian - mostly Archaean - age, i.e. of rocks that are more than 2.5 Ga old, whereas outcropping rocks in the east are of sedimentary and volcanic origin of younger Palaeozoic (= Karoo) age. There are two gaps in the stratigraphic record ranging 1) from Proterozoic to the Carboniferous, and 2) from at least Jurassic to Cenozoic times. The predominant rock types in the west are of metamorphic origin (mostly gneisses), but sometimes igneous and sedimentary rocks appear also on the surface (Brandl et al., 2006; Schlüter, 2008). Geosites with pure and entirely geological background are comparatively few and rare in Swaziland (Figure 1).

\section{Geomorphology}

Eswatini is embedded in south-eastern Africa`s landscape, which comprises a narrow coastal plain, separated from the inner southern African plateau by a horseshoeshaped escarpment. The drainage network of southern Africa is characterized by three divides, broadly parallel to the coastline. The drainage divides have been interpreted as axes of epeirogenic uplifts. The ages of these uplifts, which young from the margin to the interior, correlate with spreading regimes in the oceanic ridges surrounding southern Africa, suggesting an origin from stresses related to plate motion. Successive uplifts were focused along these axes, which initiated cyclic episodes of denudation, to be coeval with erosion surfaces recognized elsewhere in Africa. There are numerous specific landscapes in Swaziland that can be designated to episodes of these processes and may therefore represent geosites as overviewed and reflected in the following paragraph (Schlüter, 
Geosites as a Potential for the Development of Tourism - Overview of Relevant Sites in Eswatini (Formerly Swaziland)

2008; 2010). The mountainous Highveld of Eswatini is characterized by steep slopes with an average gradient of $17 \%$. Due to heavy - often human-caused - erosion in the past, the hilly areas are now dominated by rock outcrops and stony ground. Most streams are perennial and the riverbeds are generally stony as a consequence of the floods of the rainy seasons. The natural vegetation of the Highveld consists of short grassland covered by bushes and small trees interspersed with rock-outcrops.

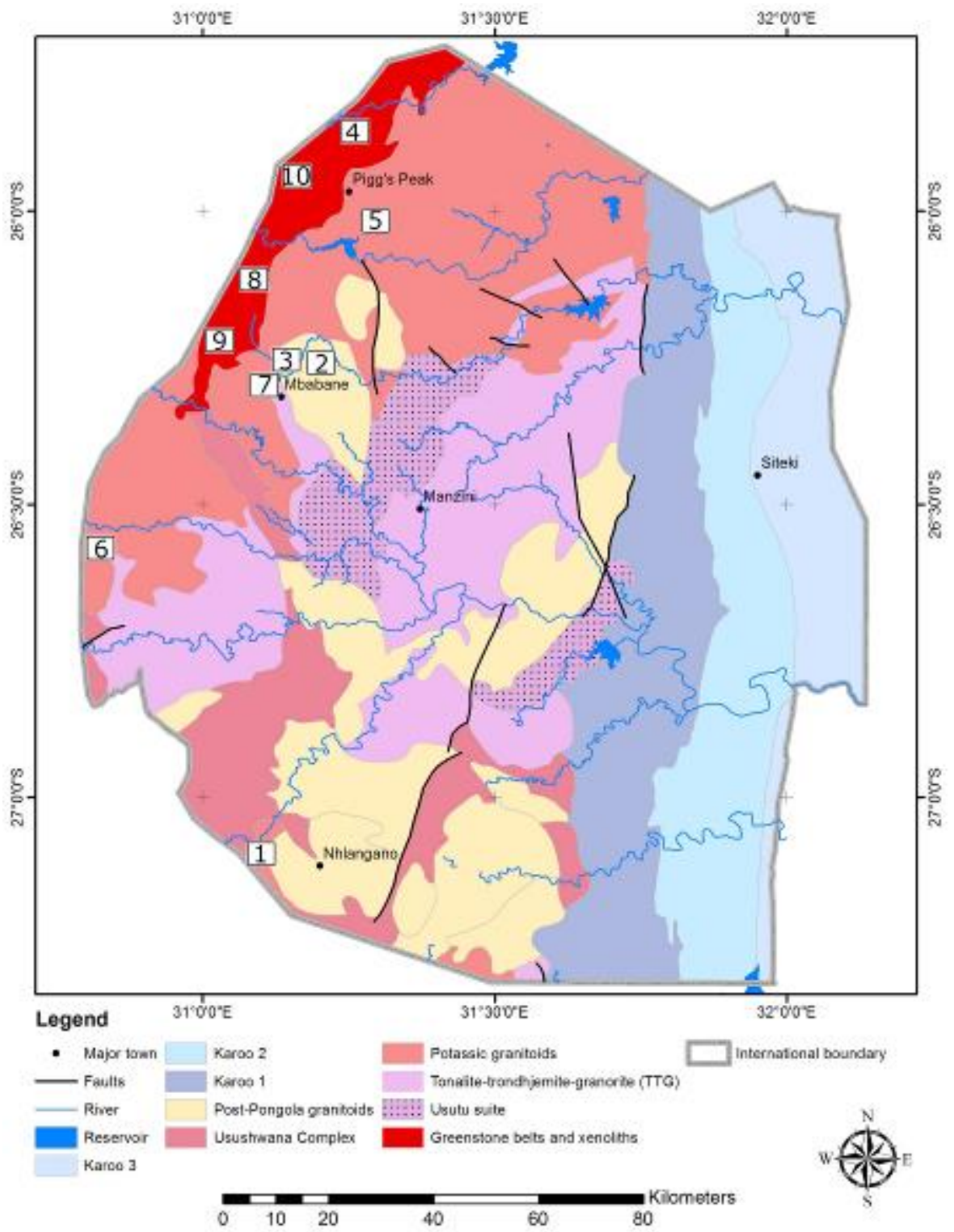

Figure 1. Geological overview map of Eswatini (formerly Swaziland) (modified after Schlüter, 2008). The numbers indicate the following geosites: 1: Mahamba Gorge; 2: Sibebe Monolith; 3: Gobholo Cave; 4: Piggs Peak gneisses; 5: Nsangwini rock paintings; 6: Sandlane rock shelter and paintings; 7: Hholoshini rock shelter and paintings; 8: Forbes former gold mining deposit; 9: Ngwenya iron ore deposit; 10: Bulembu former asbestos mine 
Wet grassland systems and spots of temperate forests can also be found, mostly in the valleys. The land has been inhabited for a long time, implying that the present vegetation is a consequence of earlier land use (with long-term grazing and fire periods). The Middleveld comprises rocks hills with granite outcrops, rounded ridges and hills with frequent valley slopes. The riverbeds generally consist of pebbles, gravel and sand. The vegetation is a mixture of temperate and tropical elements. In the Lowveld, topographic features are made of rounded ridges with gentle slopes. Around the rivers, narrow terraces composed of river alluvium occur frequently. The riverbeds mainly contain sand, but patches of gravel, pebbles and hard rock also exist. Originally the natural Lowveld vegetation consisted of woodland, dominated by large trees, but has now largely been deforested.

\section{Archaeology and Prehistory}

Archaeology is methodologically often practised and almost understood as a synonym of the term prehistory, which literally means to analyze the history of people whose cultures are lacking written documents. But sometimes archaeology includes also cultures that have invented some kind of hieroglyphs or other letter types that could be deciphered later and are thus telling us more about the history of these cultures. In Eswatini, however, human records before colonial arrival are only found without any written documentation, and their evidence is therefore largely based on the geoenvironmental context in which human sites were preserved. Based on the information now available, the archaeological or prehistoric record of Swaziland may possibly go deep into the early Pleistocene, i.e. about 2 to $1.5 \mathrm{Ma}$ ago. Isolated artefacts of a probable Oldowan stone tool industry were found among high-level Pleistocene river gravels (Price Williams, 1980; Watson \& Price Williams, 1985), which almost exclusively consist of quartzite and contain numerous crudely manufactured unifacial and bifacial chopping tools. No exact dating of this surface material is possible, but in analogy with the southern and east African dating of the Developed Oldowan artefacts an age of at least 1.5 Ma can be postulated. The more advanced Acheulean handaxe culture lasted from about 1.5 to 0.5 $\mathrm{Ma}$ and is characterized by better manufactured cleavers and choppers, which are found throughout northern Europe, western Asia, India, Indonesia, and also in large quantities in southern and East Africa. In Eswatini, Acheulean stone age sites occur for instance along the river terraces of the Komati valley, where sometimes large handaxes and cleavers were found (Masson, 2011). Apart from these remains also rock painting sites represent valuable geosites, which were used by human ancestors as shelter and for ritual purposes. The latter sites are often under threat of human-caused pollution and vandalism.

\section{Mining Heritage}

Another example of geosites is represented in former mining sites, which for instance in South Africa have already lost their original industrial function, but are currently turning to tourism for heritage preservation, regional revitalization and wider education. This in turn may serve for economic development of the surrounding communities. Eswatini was in its near past a substantial producer of asbestos, iron ore, gold and tin, but currently (2018) the mining industry accounts altogether for less than $2 \%$ of the Gross Domestic Product (GDP). As a conclusion most of the old mining sites were abandoned, but are now often used as waste dump sites, thus being an eye sore in the larger landscape and contributing to environmental pollution. Therefore an alternative use in the context of geoheritage conservation seems often possible or even necessary.

\section{EXAMPLES OF REMARKABLE GEOSITES}

\section{Landscapes and Exceptional Rock Sites}

This magnificent gorge lies west of the small town of Nhlangano off the tarmac 
road to the Mahamba border point with South Africa. A few kilometres before the border gate one has to turn right and pass the Gothic style Methodist church, which was built in 1912 and is the country`s oldest intact place of Christian worship (Figure 2). It has been thoughtfully restored and preserved over recent years, with a display board outlining the establishment and development of Christianity in Eswatini/Swaziland. The stony material used for building of the church comes largely from sandstone of Karoo age outcropping not far away in the west and south of the Mahamba gorge.

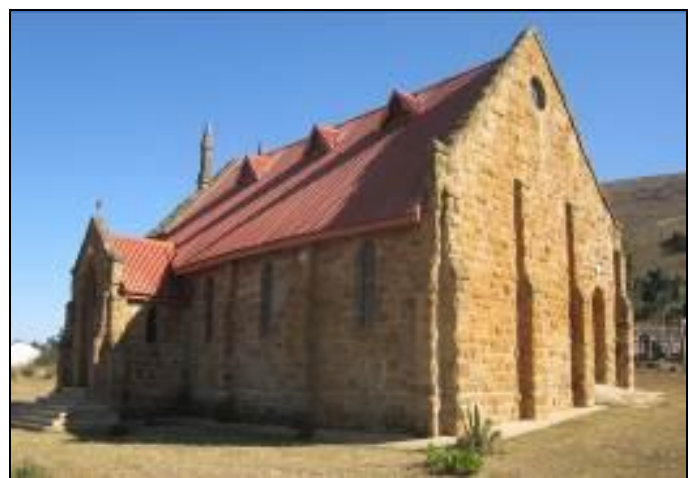

Figure 2. Mahamba Methodist Church, the oldest in Eswatini built church (1912), in 2016 by his Majesty, Mswati III, declared a National Monument

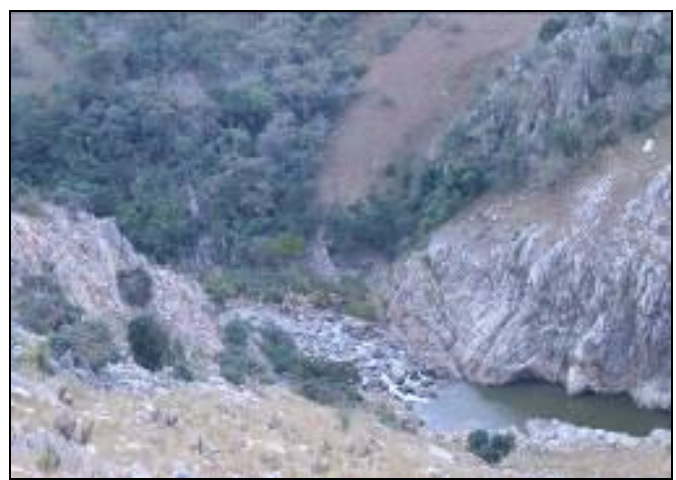

Figure 3. Mahamba Gorge near Nhlangano in SW-Eswatini. Exposed are on its sides quartzites of Mesoarchaean age of the Pongola Group

The gorge itself is cutting through Mesoarchaean quartzites of the Mozaan Group, which is part of the Pongola Supergroup leaving behind an impressive landscape where hiking is possible along a marked footpath with breathtaking views of the scenery.

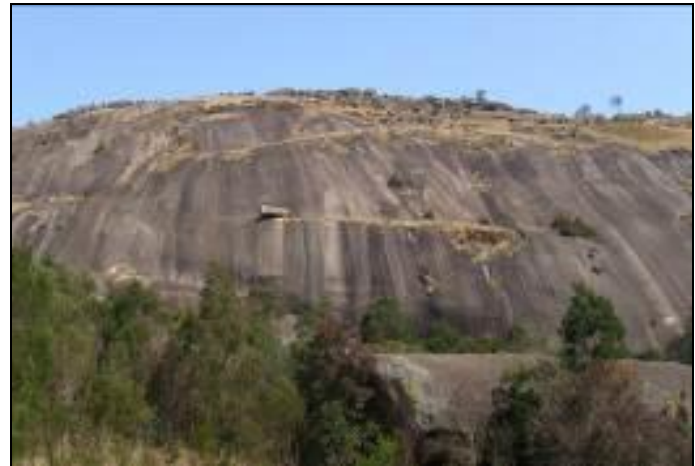

Figure 4. Sibebe Monolith in central western Eswatini, seen from its eastern flank. The rather homogenous porphyric granite has a Neoarchaean age

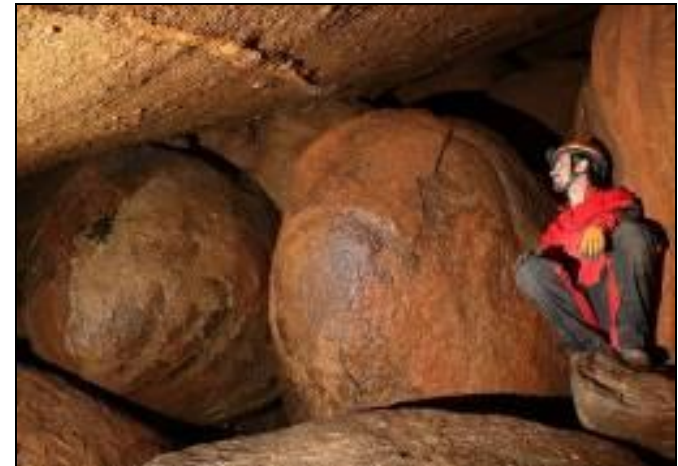

Figure 5. Rounded boulders inside of the Gobholo Cave along the flank of the Sibebe Monolith. Were these formed in situ or by movement? (M. Filippi, 2017)

Just $10 \mathrm{~km}$ east of Mbabane, the capital city of Eswatini, this large, rather homogeneous porphyritic granite monolith of probably monzogranitic to granodioritic composition is exposed. On the geological overview map of Eswatini/Swaziland this monolith is forming part of the Mbabane Pluton. The pluton or batholith formed deep in the Earth's crust during Neoarchean times, some 2.6-2.7 Ga ago, as evidenced by radiometric age determination, and was later exposed to the surface due to tectonic 
forces. Now it reaches an altitude of $1488 \mathrm{~m}$ a.s.l. In Eswatini it is assumed that the Sibebe dome after Ayers in Australia is the second largest in the world, which is debatable, but surely it is one of the biggest granitic monoliths at least in Africa. From top of the Sibebe rock a nice stunning, panoramic view is guaranteed. Hiking tours are periodically organized by the Natural History Society of Swaziland. Rather small but beautiful rapid falls appear at the foothill of Eagles Rock cutting through the Sibebe porphyritic granite. And not to forget: The most famous beer brand of Eswatini is named after the Sibebe rock. Though the adventure agency Swazi Trails, which is run by its CEO Darron Raw in Ezulwini, central Eswatini, has offered cave visits at Ghobolo for almost 20 years, not much is yet known about this site, located near Mbabane along the margin of the Sibebe Monolith (Figure 4) in largely granitic rock formations. The only scientific publications were presented by Sjöberg (2011) and Scheurer et al. (2013), who had organized expeditions into the cave and reported about their results. Research is currently undertaken by the University of Swaziland (since 2017) and a group of Czech speleologists, who visited the cave in October 2017. The Gobholo River sinks underground in the upper part of the Gobholo Valley. From there it flows nearly $1.8 \mathrm{~km}$ underground until it exits in resurgence in the lower part of the valley (Scheurer et al., 2013). Another source of moderately warm water in the Gobholo Cave has been recorded somewhere in a small middle passage of the cave, thus indicating possible influences for its formation from local thermal waters. There are two different theories for the origin of the cave (Scheurer et al., 2013). The cave is simply a huge talus cave, formed by boulders that have gravitationally been transported from the side of the valley, or (2) it is formed by deep weathering of the granite, and the boulders are therefore in situ. Most significant in the cave are numerous speleothems, forming different morphologies. Common are coralloids and flowstones, but also draperies do occur. No real stalactites and stalagmites have been found. Apparently the cave was sometimes inhabited by humans as indicated by isolated pottery findings. But scientific analysis has not yet been carried out.

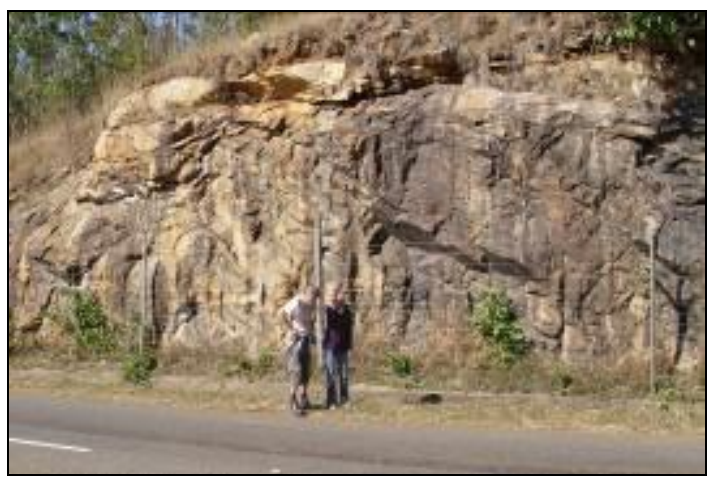

Figure 6. Road cut exposure of Piggs Peak Gneisses of Eoarchaean age, probably the oldest dated rocks in Africa (about $3.5 \mathrm{Ga}$ ), north of Piggs

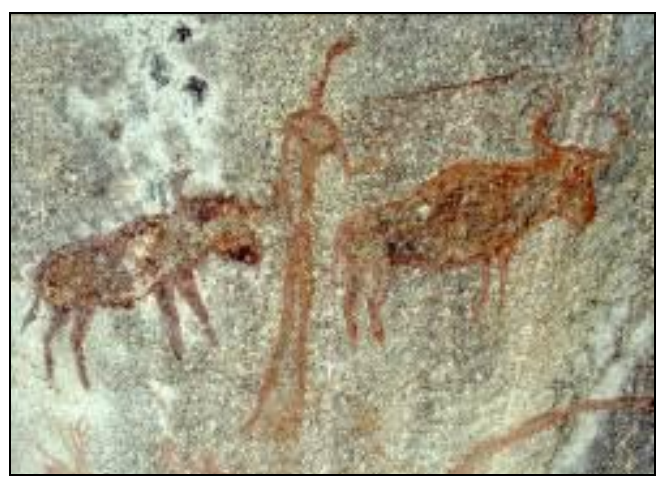

Figure 7. Rock paintings at Nsangwini showing an elongated human figure between two wildebeest

Probably the oldest dated rocks in Africa are found north of Piggs Peak (Figure 6) along a road cut, and comprise of dated Eoarchean (ca 3.65-3.64 Ga) gneisses and migmatites of the Ancient Gneiss Complex, which is called Ngwane Gneiss on the older geological overview map of Eswatini (Brandl et al., 2006). Around $3.5 \mathrm{Ga}$ ago was the time when continents started to form from the isolated cratons. It must have been a very un-pleasant time, since simple life on Earth only begun to develop around the 
same time or slightly later on this planet, as evidenced by Protozoan microfossils found in almost un-metamorphosed rocks of the Fig Tree Group of the Barberton Belt in South Africa. Rocks of this unit are also exposed in NW-Eswatini, but fossils were not yet recorded from those (Ferrar \& Heubeck, 2013).

\section{Archaeological Sites, with emphasis on Rock Painting Sites}

The three archaeological sites of Eswatini here in this review designated and incorporated as remarkable geosites are exclusively places of shelter for humans who used these locations for ritual purposes, especially in documenting their abilities in painting. Altogether at least 31 places are in Eswatini recorded where rock art has been found (Masson, 2011), but many sites are now in rather poor condition, often due to defacing by graffiti or other human caused vandalism. Better conservation measures are urgently needed. Masson (2011) has stated that more than $90 \%$ of the paintings (28 of 31) are situated on granitic country rock, whereas only two are shown on quartzite and one on gneiss. The majority of these sites are located in the western part of the country. The Nsangwini (Figure 7) site is the most famous rock painting site in Eswatini. It is sign-posted from both the Piggs Peak and Maguga Dam roads. A kiosk with an office at the end of the dirt road provides parking places and guided tours to the location in a walking distance of about half an hour. The site is a concave shelter. There are paintings of elephants in red outline, two blue wildebeest with an elongated human figure between them and a sole wildebeest at the bottom of the panel. There are also fat-tailed sheep in black, together with human figures also in black. This site contains the only depiction of felines in Swazi rock art, probably two lions. Below them on the same rock panel are a group of antelopes, including at least one eland. Human figures are either of the "match-stick" type (Masson, 2011), but most unusual at this site are two winged figures, which were after their first publication (Masson, 1961) even featured in Eswatini`s postage stamps. Nsangwini apparently contains the most diverse subject matter of all rock art paintings in the country.

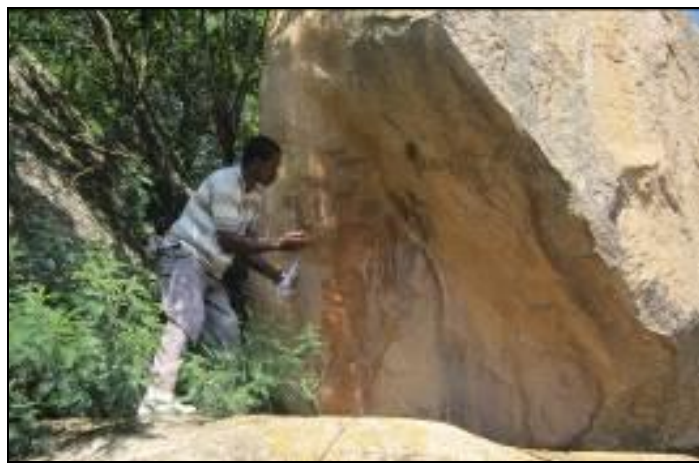

Figure 8. Rounded granitic rock shelter at Sandlane with painted animals, just being in the process of vandalism as a local guide throws water on them for better visibility, but thus contributes to increased erosion

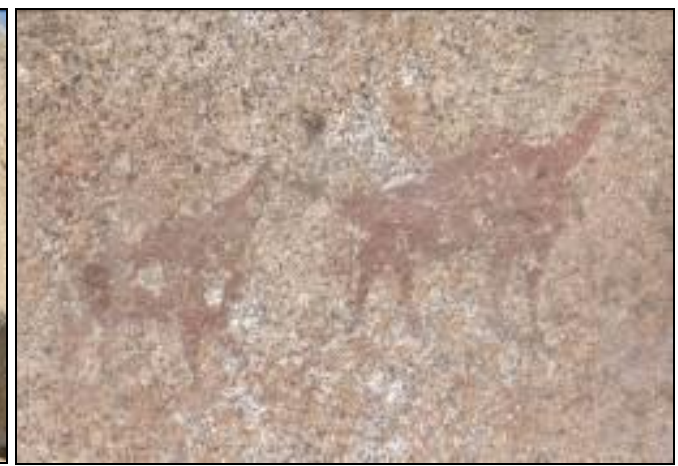

Figure 9. Two probable land animals painted on the Sibebe porphyric granite at

Hholoshini, also influenced by natural as well as human-caused erosion

The Sandlane (Figure 8) site in the south-west of Eswatini, close to the South African border, represents partially a rounded outcrop of granite, but smaller than a doomed structure, which has been split both vertically and horizontally to become a pile of boulders containing cave-like hollows and passages (Masson, 2011). Among various others, there is one animal painted, which the people of the Swazi homesteads nearby have identified as a 
donkey. Just below it is another "donkey" with an exfoliated head. But these animals represent probably zebras or perhaps the extinct quaggas. For better visibility the local guides are pouring water on the paintings, which definitely contributes to increased erosion of these rock art paintings. The Hholoshini (Figure 9) site has not been referred to by Masson (2011) and can only be traced with a local guide, near the Pine Valley road close to Mbabane. The paintings are hidden in an overhang shelter of large isolated boulders and drawn on the Sibebe porphyritic granite. The red paintings show animals, probably cattle and humans. However, the drawing of humans can only be guessed, since the site faces the threat of vandalism. Additionally, part of the paintings are already covered with a film derived from weathering solutions. Furthermore our generation added its own graffiti writings, hence the site can already be regarded as a partially vandalized location.

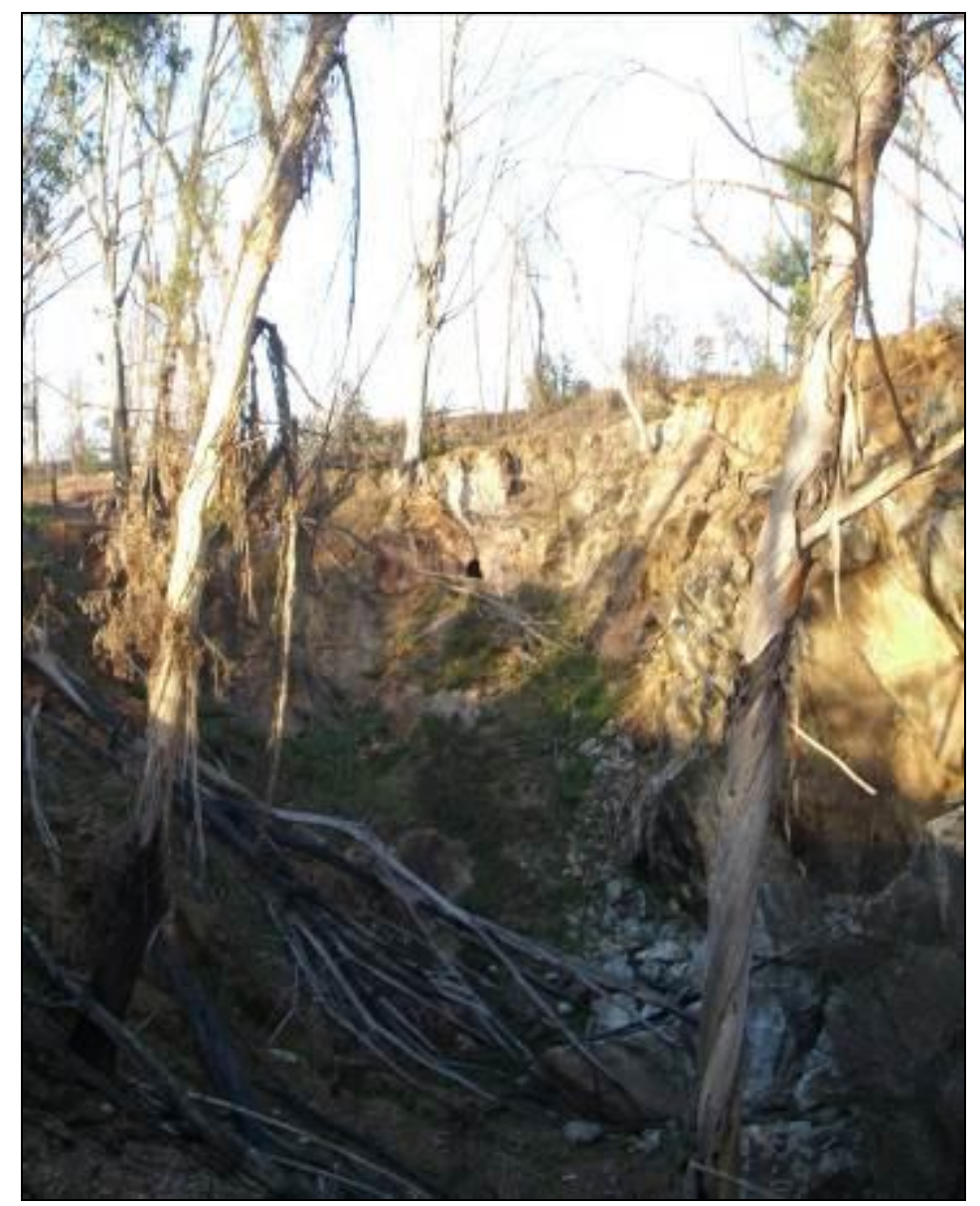

Figure 10. Former gold mining deposit Forbes inside the Malolotja Nature Reserve in NWEswatini, which may be rehabilitated for both geotouristic and commercial purposes

Mining Heritage Sites - Forbes Former Gold Deposit (Figure 10)

Gold production was always sporadic in Eswatini and prior the Boer War in South Africa (1899-1902) only mines in the Forbes Reef area attained consistent production. Gold was first discovered in the Piggs Peak area in 1883 or 1884, by members of the 
Forbes family. Forbes Main Reef produced in 1886 about 100 ounces of gold per week, but a few years later it totalled to more than 2,000 ounces per month. After some booming years all commercial work ceased in 1913, largely due to missing infrastructure as the ore had still to be brought to neighbouring South Africa. The Forbes Reef Mine finally closed down in the 1950s. On the other hand it has to be considered that Eswatini owes its initial infrastructural development from the mid-1880s till the 1950s largely to gold mining in the Hlohho District, especially the mines located at Piggs Peak and Matsamo. It was proposed by MinEx Associates, a South African based mining company, to investigate, clear and develop the Piggs Peak Mine as a National Heritage monument and educational site for tourists and the Swazi nation (Schlüter, 2013). There is still some hope that the Piggs Peak Mine may also be reopened as a production mine. It operated intermittently from 1913 to the 1950s, but was after the initial few years never profitable - despite huge investments. MinEx has promised that there will be no conflict of interest if commercial gold mining will start again there. A tourist attraction can work alongside a production facility (what may still be debated). Certain outcomes in preparing new mining facilities must initially be postulated, for example stringent control of environmental issues are necessary. Additionally, the history and relics from the past have to be recovered and restored before a new mine could destroy their evidence forever. It has also to be considered that the Forbes former gold deposit is located inside the Malolotja Nature Reserve. Currently investigations on the potentially most viable exploration and exploitation site for gold point to the Lutafu area, also close to Piggs Peak.

Former Ngwenya Iron Ore Mine (Figure 11 and 12) is located on the Bomvu Ridge, about $20 \mathrm{~km} \mathrm{NW}$ of Eswatini `s capital Mbabane. It is a sedimentary iron ore deposit and was formed during Precambrian times, around the boundary between the Archean and the Proterozoic, i.e. $2.5 \mathrm{Ga}$ ago. Its sedimentary stratification is conversantly defined as Banded Iron Ore Formation (BIF), or according to similar deposits in Brazil also as itabirites. This means a fine-grained ferruginous layer is succeeded by a much lighter jaspilitic layer, followed again by a darker ferruginous layer, and so on. However, the Ngwenya iron ore layers are generally not more in their originally horizontal position, but have been tilted (sometimes into an almost vertical position) and folded, indicating various tectonic overprints since their deposition. The area of the Bomvu Ridge was first explored in 1946, when the Geological Mines and Survey Department started prospecting in the Ngwenya Massif (Hunter, 1961). However, it had already been identified as an economically viable deposit in 1889 , but had apparently been forgotten for more than 50 years. By 1957 prospecting operations had started and reserves of ore were identified in the range of $30,000,000$ tons, with a mean value of about $60 \%$ metallic iron content.

After various infrastructural efforts commercial production of iron ore started in 1964. By 1977 the richer ores in the centre of the deposit had all been extracted, and there remained laterally on the flanks only those ores ranging from 25 to $50 \%$ iron content. By 1980 about 20,000,000 tons of the high-grade hematite had been removed, including all the stockpiles previously assembled. The mine closed in 1980 .

As still can be seen in the field and was in detail interpreted from aerial photographs of the site, large tailing deposits of iron ore are located especially along the eastern part of the industrial mining site, but are also concentrated at various other places in the area. From 2011 to 2014 these were again commercially exploited, but especially acid mine drainage polluted heavily the streams originating from the Ngwenya Massif, which essentially contribute to the water supply of Eswatini `s capital Mbabane (Fadiran et al., 2014; Thwala et al., 2014). Also floral and faunal impacts due to the new mining activities in the Malolotja Natural Reserve, of which Ngwenya is part, were unavoidable. 
Another argument for declaration of Ngwenya as a geosite (or even a World Heritage Site: Schlüter \& Schumann, 2016) is related to archaeology: Several Stone Age artifacts made of dolerite - a material which does not occur in this area - have been found in the mine during its industrial exploration in the 1960s and 1970s. These tools are more specialized than others normally found on a Stone Age site, e.g. choppers, picks and hammer stones, and were therefore identified as mining tools (Dart \& Beaumont, 1967). Radiometric dating of charcoal nodules associated with these presumable mining tools indicated between 41,000 and 43,000 years as age for their deposition (Dart \& Beaumont, 1971), thus Ngwenya may currently represent the oldest iron ore mine in the world. Red ochre from Ngwenya was extracted by ancestors of the San people and used either for ritual purposes or in rock paintings. By about 400 to $600 \mathrm{AD}$, pastoralist Bantu tribes had arrived, who were familiar with the smelting of iron ore (Figure 11), and who probably traded their metallic iron widely through the southern part of the continent. These together with the previous San people produced therefore evidence of early iron ore mining, which has led to a gradual change of tools in the region from stone tools to iron tools. Despite this legacy it is due to the recent exploitations of its tailings doubtful if Ngwenya will achieve the official status of a World Heritage Site (Schlüter \& Schumann, 2016).

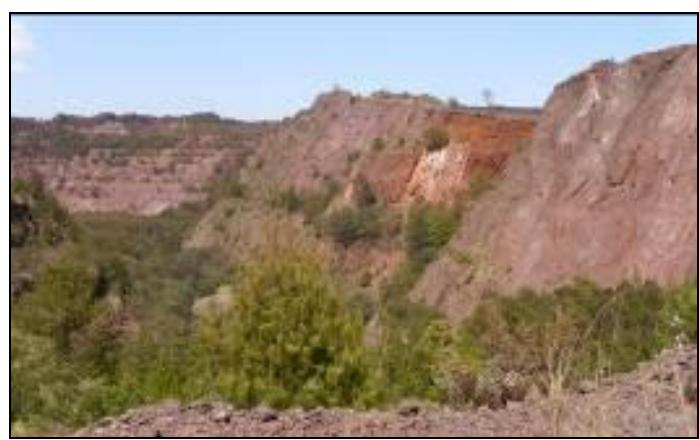

Figure 11. Former iron ore deposit Ngwenya here exhibiting what was exploited till the 1970s, mixed with large deposits of tailings that were from 2011 to 2014 resourced

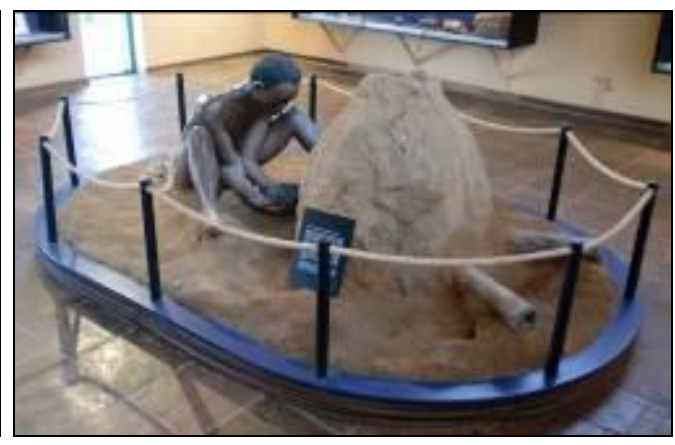

Figure 12. Reconstruction of ancient iron ore smelting by indigenous Bantu people shown in the Ngwenya visitors centre

The former Havelock asbestos mine is located at Bulembu close to the border of South Africa in north-eastern Eswatini, at the foot of the country`s highest mountain, Emlembe $(1833 \mathrm{~m})$. The rugged topography in this area is due to the underlying geology, which is part of the ancient Barberton Greenstone Belt and juxtaposes in its folded and faulted rocks soft volcanics and extremely hard, weathering-resistant cherts and sandstones. These and other rock units form some of the world 's oldest, relatively unmetamorphosed strata, which have yielded abundant information on the early history of our planet worldwide and were the main reason to designate the Barberton-Makhonjwa Geotrail, an assemblage of geosites explained in detail in the brochure of Ferrar, Heubeck (2013). Chrysotile asbestos, associated with serpentinite in a shear zone about $1 \mathrm{~km}$ wide, was mined at the Havelock mine next to Bulembu from 1939 to 2000. Chrysotile, also known as "white asbestos", is the least dangerous of the six fibrous or asbestiform minerals commonly known under the name asbestos. The crushed and milled ore was transported via a cableway (at its construction the world `s longest aerial ropeway) across the mountain to the Barberton railhead in South Africa for export. Haveloch was once the world `s fourthlargest deposit of its kind. The versatile use of asbestos allowed for profitable mining until the end of the last century when it was gradually replaced by other materials. The mine was 
sold in 1999, the new owner promptly went into bankruptcy, and Bulembu became a ghost town. The previous activities left three large, un-remediated serpentinite tailing dumps in topographically unfavourable, elevated position (Figure 12) - open to weathering and erosion, which contain about $4 \%$ of fine-grained Chrysotile fibres (Heubeck, 2017).

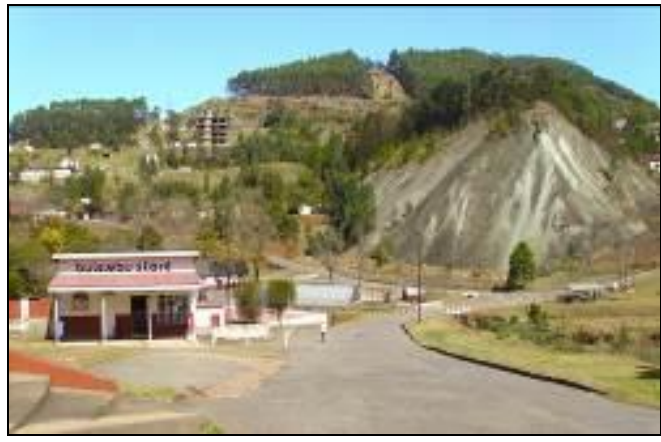

Figure 13. Large tailing deposits in the centre of Bulembu town

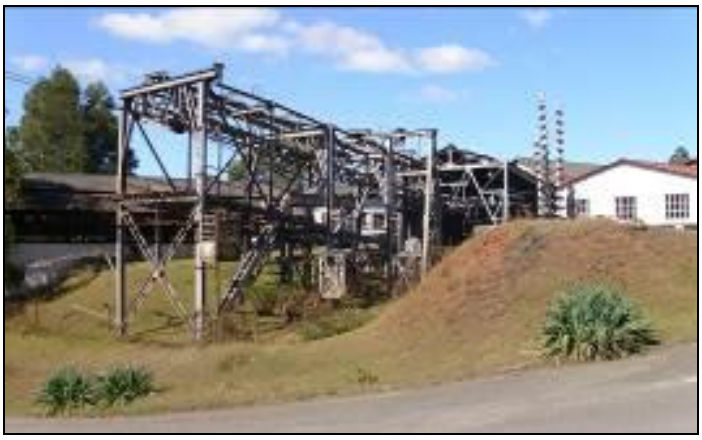

Figure 14. End-station of the cableway in Bulembu for the transport of raw asbestos to Barberton in South Africa. The building in the right is now housing the Bulembu Museum

A Christian non-profit ministry (Bulembu Ministries Swaziland - BMS) purchased the village and surrounding infrastructure in 2006 and is now running a large orphanage on behalf of the Eswatini government, moved into the abandoned Bulembu village, gradually restored many buildings and developed a number of side businesses mostly for training purposes. But the slopes of the steep tailings are still extending literally into the backyards of several buildings. Unfortunately during the past two decades it was not yet possible to re-grade the slopes or even to apply a soil cover over these. The following potential hazards remain vibrant: (1) Air contamination by short asbestos fibres on windy and dry days can never be completely excluded. (2) Mass failure of the steep dump slopes into the adjacent drainage may threaten the watershed emanating from the former mine, which flows into the Lomati River and from there into the Maguga dam reservoir (Heubeck, 2017). A museum was constructed and opened in Bulembu in 2012, largely due to the private initiative of Bob Forrester, which is housed in the old cableway station (Figure 13) and focuses in its exhibition on various environmental issues in this area. All the old machinery used during the exploitation of the mine is here shown including a comprehensive display of the former mining activities, life in a remote small town during colonial times and the natural history of the former mine`s surroundings (Forrester, 2009). According to a recent press statement (Times of Swaziland, 17 July, 2017) the tailings were sold to a Mauritius-based and South Africa-owned company, which is planning to mine the dump tailings by dissolving the serpentinite in sulphuric acid and thus producing magnesium sulphate (epsomite or Epsom salt) for sale plus the clay mineral brucite and silica as a residue. Questions remain if the recovered ore, which may additionally include exploitation of numerous minor and dormant gold deposits in the region, will contribute to enough valuable profit of this endeavour. Also the design of the remaining clay tailings is not yet clear. Currently the all-weather road from Piggs Peak to Bulembu ( $18 \mathrm{~km})$ is still in bad condition, but its transformation into a tarmac road was recently announced in a press statement. These questions gain now particular weight because Bulembu is located next to a planned World Heritage Site on the South African side of Eswatini`s border, where a major geo-touristically paved road beginning in Barberton is exhibiting unique geological examples from the early history of planet Earth. Bulembu may in this context serve as the end of this geo-trail, but represents one of the 
touristic highlights of it (Ferrar \& Heubeck, 2013). The geo-trail is equipped with welldesignated geosites and viewpoints till Bulembu on its South African part.

\section{DISCUSSION}

Most of the geosites here presented are located in the western part of the country none of them is yet indicated in eastern Eswatini (see Figure 1). What may be the reason for this curious fact? Answers arise from geological, geomorphologic and even archaeological background information: The rugged and mountainous land scenery in western Eswatini exposes per se a beautiful landscape. The Barberton Belt with its extremely diversified and ancient geological formations is embedded in the north-western Eswatini landscape. Additionally, more than $90 \%$ of the 31 archaeological sites (rock painting sites) mentioned by Masson (2011) are located in granitic rock outcrops, which are primarily found in western Eswatini. Finally, the mining heritage sites here presented are also all part of the Barberton Belt. Despite this current concentration of enumerated geosites in western Eswatini, in future additional sites may also be described from other parts of the country.

\section{CONCLUSION AND RECOMMENDATIONS}

From the examples of geosites in Eswatini here presented, it can be concluded that a sustainable geotourism approach implies that the natural, cultural and other recourses of tourism in Swaziland should be conserved for continuous use in the future, sometimes already currently bringing benefits to people in their surrounding communities. Most of the here presented examples of geosites are not only significant for a single natural scientific approach, but include also aspects of cultural identification. This joint approach is very important because development in geotourism depends largely on attractions and activities not only related to the natural environment, but often to the historic heritage and cultural patterns of the respective area (Schutte, 2009). When the original georesources are destroyed or degraded, then the geotouristic destinations will not more attract tourists. But Tourism remains an underlying force in sustainable development of the African continent (Sifolo \& Henama, 2017).

As here exemplarily indicated, some of the Swazi destinations (especially rock paintings, see Figure 8) are already under threat of vandalism, pollution or congestion. The majority of geotourists seek destinations that have a high level of environmental quality simply because they like visiting places that are attractive, clean and neither polluted nor congested. Additionally, one of the most important benefits of geotourism is that, if the respective areas are properly developed and based on the concept of sustainability, geotourism can greatly help to justify and pay for conservation of this area's natural and cultural resources. But as already outlined by Reimold et. al (2006), Swaziland needs to market its natural and cultural assets more broadly by addressing the educational tourism market more effectively. The country hosts some very spectacular geo-heritage sites not only representative for Africa, but for the whole planet Earth. Even the few examples here presented are sufficient to illustrate that Swaziland has a great potential as a destination for tourists to help understanding many aspects in the history of planet Earth, and how its human population has developed and managed to survive on it.

\section{Acknowledgements}

We thank Prof. Dr. Christoph Heubeck, Jena University, Germany, and Mr. Kurt Puttkammer, Bulembu, for their information related to the former asbestos mine of Bulembu, the Czech team of speleologists, Dr. Jiri Bruthans, Dr. Michal Filippi, Jaroslav Rihosek and Martin Slavik, as well as Mr. Darron Raw, Ezulwini, who provided photographs and information on the Gobholo Cave, and Dr. Elisabeth Linnebuhr, Mbabane, 
who has shown us the rock art paintings at the Hholoshini Shelter. Mr. Malinga and Mr. Mkhonta of the Department of Geography, Environmental Science and Planning of the University of Swaziland assisted with the production of the geological overview map. Two anonymous reviewers helped in improving content and style of the original manuscript.

\section{REFERENCES}

Brandl, G., Cloete, T., \& Anhaeusser, C.R. (2006). Archaean Greenstone Belts. In: The Geology of South Africa (Johnson, M.R., Anhaeusser, C.R. \& Thomas, R.J., eds.): 9-94: Geol. Soc. South Africa and Council for Geoscience, Johannesburg, Pretoria.

Dart, R.A., \& Beaumont, P. (1967). Amazing antiquity of mining in Southern Africa in the Middle Stone Age. Nature 216: 407-408.

Dart, R.A., \& Beaumont, P. (1971). On a further radiocarbon date for ancient mining in southern Africa. South African Journal of Science 67: 10-11.

Fadiran, A.O., Dlamini, C.L., \& Thwala, J.M. (2014). Environmental assessment of acide mine drainage pollution on surface water bodiesaround Ngwenya mine, Swaziland. Journal Environmental Protection, 2014 (5). 164-173.

Ferrar, T., \& Heubeck, C. (2013). Barberton-Makhonjwa Geotrail. Geosites and View Points. i-xii, 41 p., Barberton (Hamilton-Fynch for Batobic).

Forrester, B. (2009). A Traveller `s Guide to Swaziland. 201 p., Mbabane (Kamhlaba Publ.).

Heubeck, C. (2017). Mining, history and tailing remediation at the crossroads in Bulembu, northernmost Swaziland - Unpubl. PowerPoint Presentation, University of Swaziland: Southern African Geomorphology: Pure and Applied, Abstr. Vol., 27 slides, Kwaluseni.

Hunter, D.R. (1961, reprinted 1991). The Geology of Swaziland. Geol. Surv. Mines Department: 104 p., Mbabane.

Masson, J. (1961). Rock Paintings in Swaziland. South African Archaeological Bulletin, 16: 128-138.

Masson, J. (2011). The Archaeology of Swaziland. An Introduction. 256 p., Johannesburg, (Fishwicks Printers).

Price-Williams, D. (1980). Archaeology in Swaziland. South African Archaeological Bulletin, 35: 13-18.

Reimold, W.U., Whitfield, G., \& Wallmach, T. (2006). Geotourism potential of southern Africa. In: Dowling, R.K. \& Newsome, D.N. (eds.): Geotourism: p. 42-62: Amsterdam (Elsevier).

Scheurer, M., Lundberg, J.E.K., \& Sjöberg, R. (2013). Gobholo Cave: A Long Granite Cave in Swaziland (Southern Africa). 2013 ICS Proceedings, Karst and Caves in Other Rocks, Pseudokarst - oral, 305-307.

Schlüter, T. (2010). Highlights of the Geology of Swaziland. In: Tevera, D. \& Matondo, J.I. (eds.): Socioeconomic Development and the Environment in Swaziland: p. 30-38: Manzini.

Schlüter, T. (2008). Geological Atlas of Africa. With Notes on Stratigraphy, Tectonics, Economic Geology, Geohazards, Geosites and Geoscientific Education of Each Country (Second Edition). 307 p. + CDROM: Berlin, Heidelberg (Springer).

Schlüter, T. (2013). Energy and Mineral Resources of Swaziland: 164 p., Manzini (Blue Moon Printing).

Schlüter, T., \& Schumann, A. (2016). Use of tailings from the former Iron Ore Mine of Ngwenya, Swaziland Economic profit vs. ecologic and geo-heritage protection Zentralbl. Geol. Paläont. Teil 1, Heft 1: 75-85.

Schlüter, T., \& Tevera, D. (2016). Scientific undergraduate research in the Department of Geography, Environmental Science and Planning at the University of Swaziland- Zentralbl. Geol. Paläont. Teil 1, 2016, Heft 1: 113-127.

Schutte, I.C. (2009). A Strategic Management Plan for the Sustainable Development of Geotourism in South Africa. Ph. D. Thesis, North-West-University, South Africa, i-xviii, $463 \mathrm{p}$.

Sifolo, P.P.S., \& Henama, U.S. (2017). Implications of climate change for tourism in Africa. GeoJournal of Tourism and Geosites, year 10 (2), vol. 20: 191-198.

Sjöberg, R. (2011). Gobholo Caves, Swaziland: värdens längsta granitgrotta? Grottan 46 (4): 30-32.

Thwala, J.M., Dlamini, C.L., \& Fadiran, A.O. (2014). A study of environmental assessment of acid mine drainage in bottom sediments of dam and streams around Ngwenya iron ore mine, Swaziland- International Journal for Computer Science and Technology 5 (2): 9-16.

Watson, A. \& William Price, D. (1985). Early Pleistocene river gravels in Swaziland and their geomorphological and structural significance. Zeitschrift Geomorphologie N.F. 29 (3): 285-300; Berlin, Stuttgart.

Viljoen, M.J., \& Reimold, W.U. (1999). An Introduction to South Africa`s Geological and Mining Heritage. I-X, 193 p., Randburg, South Africa (Mintek).

http://www.geo.mtn.edu/KeweenawGeoheritage/KeweenawGeoheritage/What.html , accessed 12.05.2018.

Submitted:

27.03.2018
Revised:

24.07.2018
Accepted and published online 26.07.2018 